\title{
Political Change in Jalisco, Mexico
}

\author{
Alberto Arellano Ríos \\ El Colegio de Jalisco, Zapopan, México \\ Email: aarellano@coljal.edu.mx , betoarellano14@hotmail.com
}

Received 15 November 2014; accepted 27 November 2014; published 13 January 2015

Copyright (C) 2015 by author and Scientific Research Publishing Inc.

This work is licensed under the Creative Commons Attribution International License (CC BY).

http://creativecommons.org/licenses/by/4.0/

(c) (i) Open Access

\begin{abstract}
This paper analyzes the political change in Jalisco, Mexico. It is a panoramic work that evaluates a democratic transition at the subnational level. The work focuses on the structures of authority of the local political regime. The analytical framework used is the one proposed by Leonardo Morlino. It analyzes the document and describes the political and institutional framework of the governments divided and unified, the relationship between the powers, among other aspects.
\end{abstract}

\section{Keywords}

Political Change, Transition, Democratization, Jalisco

\section{Introduction}

This article outlines and discusses the political change in Jalisco. It basically focuses on the structures of authority and makes an assessment of the democratic journey in the western Mexican State. The study period covers the years from 1995 to 2015 . The question that articulates this text focuses on answering the following questions: in which situation is political change towards democratization; what has changed or what remains in the political regime of Jalisco; what balances that may be democratizing cruise.

The argument that articulates this document indicates that while it is true that the political change towards democratization has stagnated since structural problems persisted and institutional design, a triumph, although slight and insignificant to many, is the ability to remove and move ruler class in the structures of authority by means of the vote. This essay focuses on the structures of authority. The "political" lies and limits on this part simply by a heuristic strategy. That is why this article rests on three pillars. The first is an analytical and conceptual reflection of political change in the structures of authority of the regime. Then seeks provide clarity or make explicit the logical sense of local political change based on the conclusions made by other researchers for. Finally, from the evidence shown and what sustains this chapter, analyze the structures of authority.

\section{Political Change in the Structures of Authority}

To analyze and understand the processes of political change, political science made some concepts such as tran- 
sition to democracy or political change. And the Mexican case tried to embed in these debates and analysis schemes; but it was Merino (2003) who pointed out that our transition, unlike the international experience, was not agreed but voted. There was not a total rupture with the former regime in the Mexican transition as it consisted of transformation process in the game rules and the gradual recovery of the institutions. Therefore, the Mexican transition was slow and progressive, based on political openness, but with great risk to stagnate and possibilities of authoritarian regression (see Woldenberg, 2012; Merino, 2003) ${ }^{1}$.

But how to analytically understand the change in the political regime and why focus only on the structures of authority. To start has to be said that the decision is heuristic, and the framework of understanding is that Leonardo Morlino us formula (Morlino, 1985). Your proposal is a reaction to the way how the processes of political change were understood previously. Critical Morlino instituted models in that its proximity to the theory of political development which in turn was then as a framework a systemic functionalism, theories of modernization and the political culture. Morlino criticisms to those prospects filed in its signaling that even if they wanted to become embedded as theories of intermediate-range, according to the terms of Robert Merton (1984), were still general proposals and macro.

In this sense, Morlino elaborates a proposal, yes generalization, but according to the more suitable to explain the change to the interior of the system. His proposal sought to: a) escape determinism social, economic, and cultural; b) placed in the middle of the macro and micro theory; c) obtain a concept that was efficient and clear in the flat empirical; d) use the data, even the historical purposes explanatory (Morlino, 1985: p. 50-80).

What Leonardo Morlino questioned the way to understand the political process so far, was the historic anchor of the concepts and that the category of political development was not the same or equal to political modernization. Based on this premise, political change, political development and political modernization are not comparable (Morlino, 1985: p. 28-29). Precision were not only conceptual but a pointing, more clear in a later work, that political change also occurs and is not in the direction of democracy to an authoritarian and totalitarian regime (see Morlino, 2005). Then then, made the previous accuracy, political change is equivalent in exchange for or in the political system (Morlino, 2005: p. 30), and indicates what a process or a movement without lineal valuation issues as it was the transition to democracy.

Done, the consequent problem consisted in setting the characteristics of the political system. So Morlino differed three areas or pillars which is supported politically, and therefore space system to observe changes and the continuities in their different shades and grades. The first pillar and of the political system is the political community, the second political regime and the third authority. In the political community manifested the ideologies, values and beliefs, dominant or competitive situation, as well as persons or active groups and some structures intermediate (not always present in the political community). For what have the political regime if it is true that in this area are expressed ideology, values, key beliefs or in competitive situation, in this space and clearer express norms or rules, decision-making structures and the structures of authority. Finally, this distinction of the parts of the political system led to Morlino, to appreciate that the third pillar is the level of authority and they distinguish the titular roles and interaction of the actors from the positions which are occupied in the structures of authority and decision-making (Morlino, 1985: p. 45-46).

In this sense, or a regime change is a frequent phenomenon of great importance that can affect all political systems. It is a change that is often seen in the historical processes and of great importance as it has repercussions in the lives of millions of people (Morlino, 1985: p. 81). In addition, emphatic Morlino says that the political regime is not equal to the political system. Also the values, doctrines and ideologies only can be considered important when they can count on available data. In short, political analysis, the object study of change is the rule and not the system because the system comes from the scheme but undoubtedly affects it, hence, the more frequent and palpable change occurs in the intermediate structures (parties and political groups) and the authority: occupying subjects, roles and periods, and of course all this affecting political orientation so there is sense and direction in the political system (Morlino, 1985: p. 81).

In short, in the previous framework this chapter display political change in Jalisco and tries to analyze the transition from one political regime to another and see what changes or remains either what or which political

\footnotetext{
${ }^{1}$ The empirical basis on which it was built was and the political change had the historical experiences of countries in the Mediterranean Europe, Latin America and Eastern Europe where a totalitarian or authoritarian by one more or less democratic regime was replaced as sustenance. Thus, the political changes in the world were conceived and interrelated either on the shaft of a great national transformation as raised Manuel Alcántara, a political transition as Samuel Huntington, Juan Linz, Guillermo O'Donnell and Philippe Schmitter, or in the variant of a great political change national as Leonardo Morlino or Adam Przeworski (Acosta, 2000: p. 20).
} 
system has become. It is true that the objective of the proposal for Morlino is to develop taxonomies, classifications, see the variables, indicators of the degree of democracy and authoritarianism in perspective compared to analyzing national political systems. But applied to the case of Jalisco its analytical framework has two intentions: 1) allow conceptual precision, and 2) heuristically delimit parts of the political system will be analyzed. However, before doing so is necessary to realize the sense that political change in Jalisco has had according to several investigations, and in the third party conduct an assessment of the political change and take the pulse in your path towards democratization.

\section{The Sense of Political Change in Jalisco}

In the study of the change and the Mexican political transition there was two large positions to understand and explain it: the first was linked to electoral issues while the other is linked to how political processes and transformations of the regime are linked to wider social and economic processes. In this way, we can say that if the first perspective relates to the legitimacy of origin, the second cares about the legitimacy in the exercise of power. We also can say that if the electoral question corresponded to a package of problems first generation, the second involved being attentive to the problems of second generation in Mexican democracy (Aziz, 2003: p. 99-121).

As for the Jalisco case we can say that it has tried to insert in the former social and historical context, which resulted that the academic community of Jalisco not only take the pulse of political change at different times, but be aware of the nature and location of the political transition in general. So when the Partido Acción Nacional (PAN) won the governorship of Jalisco in 1995, all the city halls of the Area Metropolitan of Guadalajara and other major State, as well as the majority in the local Congress, Jorge Alonso settled at that time which had taken a pragmatic and non-programmatic alternation in Jalisco (Alonso, 1995: p. 205-208). This since the PAN victory was unexpected and such situation did not have a clear government program that actually meets in a profound change of the political system.

The distance the consensus says that the Partido Revolucionario Institucional (PRI) lost because the regime in Jalisco has worn off at four levels: at first when the traditional channels of participation (corporatism) made crisis; the second crisis occurred in the non-competitive party system; the third crisis arose when there was a mismatch between the demands and the inability of the institutions for resolving them; the last one in the break given the political pact that claimed the elite that had monopolized power (Gómez, 1997: p. 182).

Already installed in the Government, the PAN, and soon to observe their performance, led to disappointment citizen, which quickly buried the idea of that the alternation as the essential of the transition policy towards democratization and as central vector of explanation, had run its course. It was so, and starting from the Jalisco case, which came to hold that in Mexico has raised a political change which not resulted in a change in the making of public policy, that is, that arise a political change without change in the form of formulating public policies (Acosta, 2004: p. 54-55).

The second Government of Francisco Ramírez, PAN marked clearly the disappointment with the electoral process so far lived. It was noted that it could have governments elected democratically, but this did not mean that Governments were. And it was the third Government PAN, that of Emilio González, who sealed as definitive proof that the formal and electoral element which democracies use to legitimize himself was insufficient. In this way, and seen as a political medium-term, and prior to the 2012 elections process, the intermediate elections of July 2009 were a cut of box alternation in 1995. In the 2009 election Jalisco evaluated a way to govern and not a Government in yes (Arellano, 2011b).

It is true that the election results and joints realize changes in the political positions of the political regime, but a more comprehensive assessment has been that the political change in Jalisco has been cut short or intermittent since there is a "partidocracia" that violates democracy (Aziz \& Alonso, 2009). There is a monopoly shared between political parties (Guillén, 2005), or that it is also cut short, intermittent or limited due to the existence of a field of power that opposes its democratization (Arellano, 2011). However, a panoramic analysis of the changes in the structure of authority, as well as of the institutional relationships established in the political regime in the period of 1995 to 2012, indicates that democratic and at the same time changes there are authoritarian inertia in political system.

But the most significant balance of political change and the cycle that closed in 2012 and that is not limited to one political party in particular is that the alternation was emptied of democratizing element (Alonso, 2010: p. 
245-254). Thus, it is valid to Gaetano Mosca quote where it says that in the process of political transition does not change the fact that there is a political class but its quality, its composition, formation and organization (Mosca, 1984: p. 11). Therefore, closes a cycle in the part more visible and important for the political regime: the Executive. The PAN leaves this position to open up another stage of PRI Government. But rather than get into the Constitution of a political class be observed generally the positions in the structures of authority.

\section{The Structures of Authority}

In Jalisco, as in much of the country, a long political transition was linked to the phenomenon of party alternation where the PRI lost positions, already out in local councils, congresses, and Executive. These, besides being the most clear and evident in the structures of political regime, are the places where the opening is and political pluralism. In this sense, voted "transition" (Merino, 2005) placed the electoral vector as the nodal element with which analyzed political change towards democratization. But once located the alternation in their fair dimension is observed, on the one hand, that it was in the simple release and circulation of the political class in a formally democratic regime and, on the other hand, as an element that might explain the sanction to the performance of Governments and political actors.

Therefore must be considered how the election results mean positions and establishing an institutional framework. This framework certainly conditions the institutional performance of Governments, but to be the political system of Jalisco a presidential regime, it is important to take into account this position and its relationship with the local Congress.

\subsection{The Electoral Vein}

Roughly in the process of political change in Jalisco, and valued on the electoral side, you can see clearly that during the period from 1979 to 2012 was the transit of a hegemonic party to a moderate multi-party system; before had gone through a system that tended to bipartisanship in practice (see Cortés \& Ortiz, 2007). In the graph it can noted that hegemonic party system says final goodbye and the bread is important spaces of the structures of authority.

In 1995 clearly wins the State Executive, the mayoralties of the Guadalajara metropolitan area and other major of the State as well as the majority in the local Congress. The pragmatic and non-programmatic alternation (Alonso, 1995: p. 204) which was driven by the events of the explosions of April 22, public insecurity, the murder of Cardinal Juan Jesús Posadas Ocampo, the mistake of December 1994 with the economic crisis that unleashed, among other circumstances arose.

In 1995 clearly wins the State Executive, the mayors of the area should be noted that the results which look at the transition and evolution of the party system are those of the election of deputies by relative majority. This is because such results, in addition to following the premise that the electoral system tries to convert votes into seats, their percentages determined the integration of the local Congress by two principles: that of relative majority and proportional representation. On this basis, it is necessary to point out that, in 1995, national action won the $53.9 \%$ of the vote in the election of Deputies. Since then it has not passed the threshold of $40 \%$ of the votes cast. This appreciation same extends to the PRI (see Figure 1).

That is why the 1995 election should be considered as the precipitous fall of the PRI in electoral terms and that the change in the political regime has had a connotation towards democratization in the political community. In contrast, the choice of 2009 and 2012 are manifestations of a process of political change, but now because it closes a cycle of PAN in the Executive Governments: political change was then limited to an important position in the structures of authority (Figure 1).

This same may indicate a value meaning that political change as a process towards democratization stagnated or has been limited to institutional and formal part of the political regime, and in the worst cases they must deal with who the positions of authority. The change is then confined to a matter of circulation and renewal of the political class: an important element in formal but insufficient democracy. The challenge is that democratization is moved to entire political system in two ways: in the same political regime toward greater democratization incorporating citizen participation in terms of true and greater places of decision, and in the political community with really build ideas, values, and more democratic practices.

The political struggle for positions in the structures of authority was limited real and effective polítticas between two forces. This happens with clarity in the period encompassing the elections from 1997 to 2009. In it, 


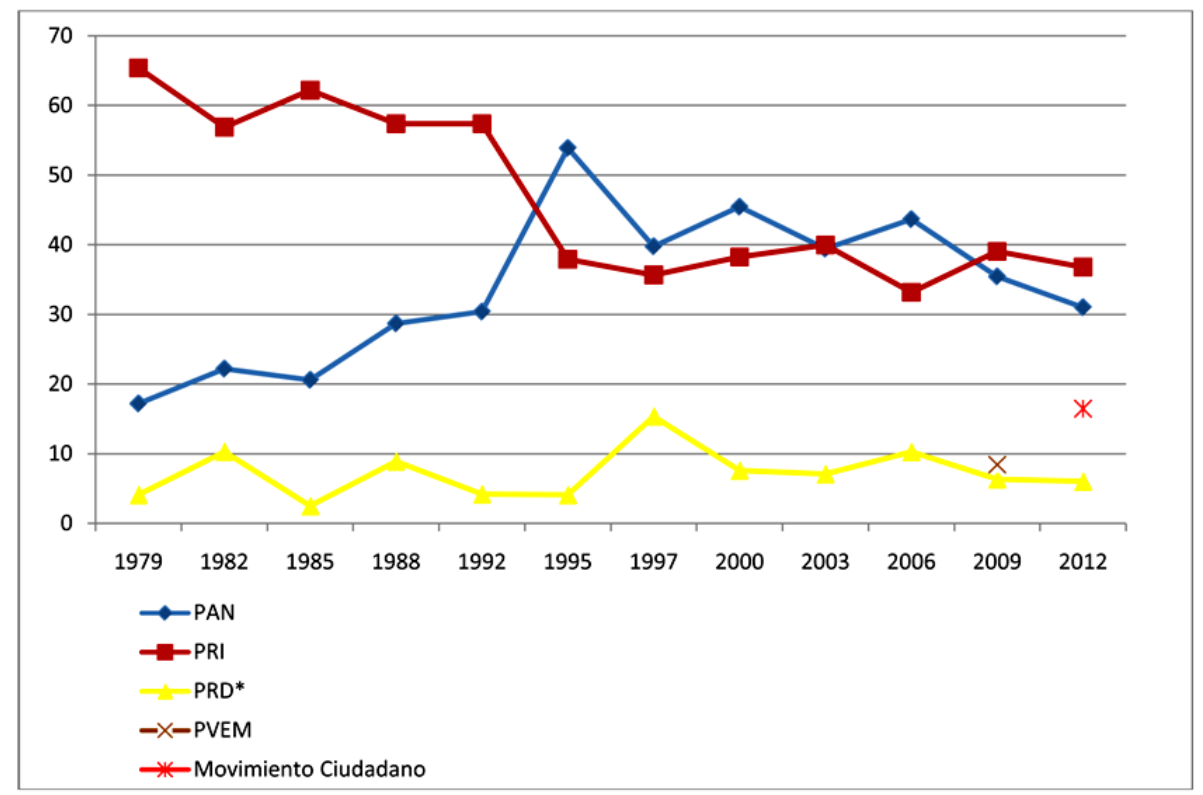

Source: own elaboration. On the average of the PRI are referred to the Alliance in 2009 and 2012. *: the PRD considers the results of left-wing parties that preceded it.

Figure 1. Election of deputies by the principle of relative majority (1979-2012).

there are variations and subtle changes in the electoral preference between the PRI and the PAN, but is PAN who won most of the time, that yes with a minimum advantage. In the election for deputies in 2003 alone there were a "technical draw" having both forces policy $39 \%$ of electoral support. However, we can say that the choice of 2009 in 2012, and in real terms, what can be seen is that these two political forces have lost electoral support significantly (Figure 1).

With regard to the municipal level, it should be noted that up until the 2012 election, the only municipality not of the 125 existing in Jalisco, and that he did not know the alternation, it was la San Cristóbal de la Barranca. But already seated in the local political system, the alternation is confined to element relay and "turnismo" in the political system. The case of the Metropolitan Area of Guadalajara is an example of this. In this way, it is necessary to make the election question aside to be more attentive to the results or consequences that the electoral system in the structures of authority of the political regime. This is why you first sketch the institutional framework that is conditioned on the political regime.

\subsection{The Conditioned Institutional Framework}

Be aware of the positions of political actors and the political parties, shall take into account not only the established framework but the way how must condition relations between actors and political institutions. Therefore you will be facing the line of the development of the regime and of much of the political system. Then the analysis is located on the other side of the issue: the positions actually obtained and occupied in the structures of authority of the political regime. It will be realizing some initial estimations of its institutional performance, and on this flank of the political regime is there anything settle, an element or structural presidential government system problem: the existence of divided government.

Alberto Aziz had already noted that in the Mexican political transition took place first alternation and then the phenomenon of divided government (Aziz, 1996). And in the case of Jalisco, and as a result of the process voted transition made democracy (Merino, 2005), it is clear that from 1995 to 2015, in the seven legislative periods in the congress of Jalisco and its relationship with the Executive Branch (see Table 1), in four divided government institutional environment and two of no unified Government. Divided government is usually, and framed in the presidential regime where there is separation of powers, the situation in which the party of the executive does not have absolute majority in the congress $(50 \%+1$ of the seats). But more accurately, Javier Hurtado says that divided government is: 
Table 1. Relationship executive-legislative in Jalisco (1995-2015).

\begin{tabular}{|c|c|c|c|c|c|c|c|}
\hline & \multicolumn{2}{|c|}{ Alberto Cárdenas (PAN) } & \multicolumn{2}{|c|}{ Francisco Ramírez (PAN) } & \multicolumn{2}{|c|}{ Emilio González (PAN) } & \multirow{2}{*}{$\begin{array}{c}\text { Aristóteles Sandoval (PRI) } \\
\text { LX }\end{array}$} \\
\hline Legislature & LIV & LV & LVI & LVII & LVIII & LIX & \\
\hline Type of government & Unified & Divided & Unified & Divided & Not unified & Divided & Divided \\
\hline The party of the governor seats & 24 & 19 & 21 & 19 & 20 & 17 & 17 \\
\hline Seats of the opposition & 13 & 21 & 19 & 21 & 20 & 22 & 22 \\
\hline
\end{tabular}

Source: Own elaboration.

... aquél en que la mayoría de la cámara pertenece a un partido y el presidente (o gobernador) a otro. $\mathrm{Y}$ al contrario, cuando un partido pose el control, tanto del ejecutivo como del legislativo, unicameral o bicameral, se habla de gobierno unificado, mientras que cuando nadie cuenta con mayoría (absoluta) congresional se habla de gobiernos no unificados (Hurtado, 1998: p. 46).

Then a unified government is the situation in which the party of the governor has half plus one of the seats. But in the case of Jalisco to speak of a government not unified, and not having a bicameral system, refers to the situation in which the party of the governor has half of the seats and the opposition as a whole the other half. There is then a tie situation.

Thus, PAN (1995-2012) had been in the period of governments, and according to Acosta (2011: p. 195), "a law of alternation bronze". This is when I was in game the election of governor of the Executive party had majority in the local congress, which was seen as a great triumph. However, in the mid-term election there was inevitably a defeat which was seen as a punishment. This act ceases to operate in the 2012 election, when now the PRI as a winning party in the position of the executive did not obtain the majority that in the case of the PAN Governments rose during the first half of the executive management (see Table 1).

No doubt this situation would that in the context of divided governments arose between the executive and the legislature the intensification of the use of the veto in our political system. This idea expressed with clarity, would indicate that this mechanism will increase in the second half in the period of the Executive. However, in this there were faults (see Arellano, 2011a).

In the Jalisco experience it came to pass, and view this relationship within the framework of the confrontation or paralysis that conditions the government divided and as a consequence of the election results, which certainly veto appeared with greater glow in the second half of the reign of Alberto Cárdenas, when it vetoed six decrees or laws. But the relationship between divided government and veto is not so convincing, since then the Francisco Ramírez vetoed the same number of laws or decrees in a context of unified government. It is true that Ramírez Acuña vetoed provisions on nine occasions laws and decrees in a context of divided government and therefore greater in quantity, but it is striking that the veto is not correlated with the divided government. The case of the government of Emilio González could seal this appreciation when in a context of unified government that was raised in the first half of his government, vetoed on eight occasions various laws or decrees of the congress of Jalisco (see Table 2).

In Jalisco the premise that the establishment of a divided government could intensify the use of the veto by the Executive was not clear and convincing. The brief historical and social experience was not for institutional explanations of causal type, either which was not in a linear vision of the integration of the congress, discipline or party indiscipline as permanent and solid factors explaining it, but that they were other factors and characteristics of the political field of Jalisco. The challenge was to locate the structural and cyclical elements of what really was at stake (see Arellano, 2011a: p. 57; Arellano, 2011c: p. 47-90).

It is important to bear in mind this institutional framework and add another. In the previous logic should be placed equally positions and the control of the municipalities of the metropolitan area as the territory where establishing the political arena. These positions are important because control of the capital and in the municipality of Zapopan, or another and at times was that of Tlajomulco de Zuñiga, conditioned, along with the control of the Executive and obtained positions at the congress of Jalisco, a context that could explain different joints.

It is significant to note that during 15 years of rule PAN in the Jalisco capital (1995-2009), and then in the case of the triumph of the PRI in 2009-2012, recent history indicates that the last three governors have been 
Table 2. Decrees vetoed by the executive (1998-2012).

\begin{tabular}{cccccc}
\hline Governor & Alberto Cárdenas Jiménez & Francisco Ramírez Acuña & Emilio González Márquez & Total \\
\hline Legislature & LV & LVI & LVII & LVIII $^{*}$ & \\
Number of vetoes & 6 & 6 & 9 & 8 & 29 \\
\hline
\end{tabular}

Source: Own elaboration. * Data considered until December 2012.

Table 3. The control of the municipalities in the metropolitan area of Guadalajara (1995-2015).

\begin{tabular}{|c|c|c|c|c|c|c|c|}
\hline \multirow{2}{*}{$\begin{array}{l}\text { Political } \\
\text { party }\end{array}$} & \multicolumn{2}{|c|}{ Alberto Cárdenas (PAN) } & \multicolumn{2}{|c|}{ Francisco Ramírez (PAN) } & \multicolumn{2}{|c|}{ Emilio González (PAN) } & \multirow{2}{*}{$\begin{array}{c}\text { Aristóteles Sandoval (PRI) } \\
\text { 2012-2015 }\end{array}$} \\
\hline & 1995-1997 & $1998-2000$ & $2001-2003$ & 2004-2006 & 2007-2009 & $2010-2012$ & \\
\hline PAN & $\begin{array}{l}\text { Guadalajara, } \\
\text { Zapopan, } \\
\text { Tlaquepaque, } \\
\text { Tonalá, } \\
\text { Tlajomulco de } \\
\text { Zúñiga, El Salto }\end{array}$ & $\begin{array}{l}\text { Guadalajara, } \\
\text { Zapopan, } \\
\text { Tlaquepaque }\end{array}$ & $\begin{array}{l}\text { Guadalajara, } \\
\text { Zapopan, } \\
\text { Tlaquepaque, } \\
\text { El Salto }\end{array}$ & $\begin{array}{l}\text { Guadalajara, } \\
\text { Tlajomulco } \\
\text { de Zúñiga, } \\
\text { El Salto }\end{array}$ & $\begin{array}{l}\text { Guadalajara, } \\
\text { Zapopan, } \\
\text { Tlaquepaque, } \\
\text { Tonalá, } \\
\text { Tlajomulco } \\
\text { de Zúñiga }\end{array}$ & & \\
\hline PRI & & $\begin{array}{l}\text { Tonalá, } \\
\text { Tlajomulco } \\
\text { de Zúñiga, } \\
\text { El Salto }\end{array}$ & $\begin{array}{l}\text { Tonalá, } \\
\text { Tlajomulco } \\
\text { de Zúñiga }\end{array}$ & $\begin{array}{l}\text { Zapopan, } \\
\text { Tlaquepaque, } \\
\text { Tonalá }\end{array}$ & El Salto & $\begin{array}{l}\text { Guadalajara, } \\
\text { Zapopan, } \\
\text { Tlaquepaque, } \\
\text { Tonalá, El Salto }\end{array}$ & $\begin{array}{l}\text { Guadalajara, Zapopan, } \\
\text { Tlaquepaque, Tonalá, } \\
\text { El Salto }\end{array}$ \\
\hline PRD-PT & & & & & & $\begin{array}{l}\text { Tlajomulco } \\
\text { de Zúñiga }\end{array}$ & \\
\hline $\begin{array}{c}\text { Movimiento } \\
\text { Ciudadano }\end{array}$ & & & & & & & Tlajomulco de Zúñiga \\
\hline
\end{tabular}

Source: Consulted in December 2012.

mayors of Guadalajara (Francisco Ramírez, Emilio González and Aristóteles Sandoval), so this role is a very important incentive for the politician who wants to be Governor previously attempt to be the Mayor of Guadalajara in the three years prior to when the State Executive is elected.

In addition to that in the period of 2010-2015, bread did not obtain any Mayor of the municipalities that make up the metropolitan area. For a long time political competition was between the PAN and the PRI. While in 1995 the PAN swept in the 1995 election, in the period ranging from 1998 to 2009 electoral processes of high competition between both political institutes for control of metropolitan councils were raised, and it is clear unless the PAN lost the municipality of Guadalajara. The situation changed when in the 2009 election bread was almost relegated from the metropolitan scene. The PRI took during two periods (2010-2015) control of five councils among them on the capital of the state, as well as a political group with the seal of different minority parties in the two periods concerned, the control of the municipality of Tlajomulco de Zúñiga (see Table 3).

\section{Conclusion}

$\mathrm{Al}$ delineates that the institutional framework can be glimpsed which starts a cycle of political openness of political regime since the 1980s. The choice of 1995 is a landmark date in local political alternation and he wanted to equate with the 2012 but it is not. It was confirmed that the electoral element of change is nodal but at the same time it is part of a broader process in which even installing a formally democratic regime in the line of the government performance is more important.

However, the 2012 elections in which the PRI won the Executive closed cycle PAN governments, hence, its meaning. While it is true that the PAN governed the state for 18 years, it was not a period of political party. Governmental actors and political parties have coincidences in his move which places change in aspects such as ideas, values, and practices that are not democratic, ergo it is concluded that the political shift to democracy has stalled. In this part of the political regime, real change is still far away. We are in a situation in which democratizing tendencies and authoritarian inertia are given; this is the paradox (see Aziz, 2013: p. 41-62). 
There were also visible elements of change in the political regime in Jalisco. Changes in the formal rules of play were raised and positioned the mobility and greater competition in the positions in the authority of the local government structure. The most important and visible changes were a) travelling a hegemonic party to a multi-party system; b) that the political regime set up divided governments; c) that the alternation was now a simple relieved. Though dimly, in the end you can see that the voters reward and punish political forces. Therefore, you value the government performance. In the end, it is concluded that voters do not have any owner. In this way, voters don't have any owner to penalize and reward the incumbent Government. But the fact that voters are not owned by anyone is best understood when making a crossover vote. This determines that there is fragmentation of power in the political arena. The challenge now is to be more aware of government performance, which is the other side of the coin in the processes of political change. And although the electoral element of the Mexican transition is criticized for the disappointments, be emphatic in pointing out that there is no political democracy without free elections. Periodic and reflecting competition is not possible to speak of a formally democratic regime. This is the change which should be valued and defend.

\section{References}

Acosta, A. (2000). Cambio Institucional. In L. Baca et al. (Eds.), Léxico de la política (pp. 19-22). México City: FCEFLACSO-CONACYT.

Acosta, A. (2004). Poder político, alternancia y desempeño político. La educación superior en Jalisco, 1995-2001. Estudios Sociológicos, 64, 53-78.

Acosta, A. (2011). Jalisco 2009: Los votos y las causas. In M. C. Cortés, \& D. Gómez (Eds.), El voto en Jalisco: Crisis, elecciones y alternancia 2009 (pp. 193-204). Guadalajara: IEPC-Universidad de Guadalajara-ITESO.

Alonso, J. (1995). El cambio en Jalisco. Las elecciones en 1994 y 1995. Guadalajara: Consejo Electoral del Estado de Jalisco-Universidad de Guadalajara-CIESAS.

Alonso, J. (2010). Alternancias municipales en Jalisco. In M. A. Cortés, \& D. Gómez (Coords.), El voto en Jalisco: crisis, elecciones y alternancia 2009 (pp. 245-254). Guadalajara: IEPC-Universidad de Guadalajara-ITESO.

Arellano, A. (2011a). El veto en Jalisco (1998-2009). Estudios Jaliscienses, 86, 45-57.

Arellano, A. (2011b). Los gobiernos panistas de Jalisco: cambio político y desempeño gubernamental. Espacios públicos, 30 , $138-154$

Arellano, A. (2011c). Campo politico. Zapopan: El Colegio de Jalisco.

Aziz, A. (1996). Alternancia primero, gobierno dividido después: El caso de Chihuahua, 1992-1996. In A. Lujambio (Ed.), Gobiernos divididos en la Federación mexicana (pp. 99-127). México City: UAM/IFE/Colegio Nacional de Ciencias Políticas y Administración Pública.

Aziz, A. (2003). Problemas de primera y segunda generación en la democracia regional mexicana. Espiral. Estudios de Estado y sociedad, 27, 99-121.

Aziz, A. (2013). Paradojas electorales de 2012. Desacatos, 42, 41-62.

Aziz, A., \& Alonso, J. O. (2009). México, una democracia vulnerada. México City: CIESAS-Miguel Ángel Porrúa.

Cortes, M. A., \& Ortiz, I. (2007). Jalisco: Democracia electoral con déficit de legitimidad política. Espiral: Estudios de Estado y sociedad, 13, 45-80.

Gómez, A. (1997). Crisis y transición en Jalisco. Guadalajara: Universidad de Guadalajara.

Guillén, T. (2005). Frontera norte: Agenda (pendiente) de modernización política. In A. Aziz, \& J. Alonso (Eds.), El Estado mexicano: Herencias y cambios. Globalización, poderes y seguridad nacional (pp. 389-403). México City: Cámara de Diputados-CIESAS-Miguel Ángel Porrúa.

Hurtado, J. (1998). Los gobiernos divididos y las elecciones de 1998 en México. Este País, Núm. 85. http://estepais.com/inicio/historicos/85/11_ensayo_divi_hurtado.pdf. Accessed May 2012

Merino, M. (2003). La transición votada. Crítica a la interpretación del cambio político en México. México City: FCE.

Merton, R. (1984). Teoría y estructuras sociales. México City: FCE.

Morlino, L. (1985). Cómo cambian los regímenes politicos? Madrid: Centro de Estudios Constitucionales.

Morlino, L. (2005). Democracias y democratizaciones. México City: Centro de Estudios de Política Comparada AC.

Mosca, G. (1984). La clase política. México City: FCE.

Woldenberg, J. (2012). Historia mínima de la transición democrática en México. México City: El Colegio de México. 
Scientific Research Publishing (SCIRP) is one of the largest Open Access journal publishers. It is currently publishing more than 200 open access, online, peer-reviewed journals covering a wide range of academic disciplines. SCIRP serves the worldwide academic communities and contributes to the progress and application of science with its publication.

Other selected journals from SCIRP are listed as below. Submit your manuscript to us via either submit@scirp.org or Online Submission Portal.
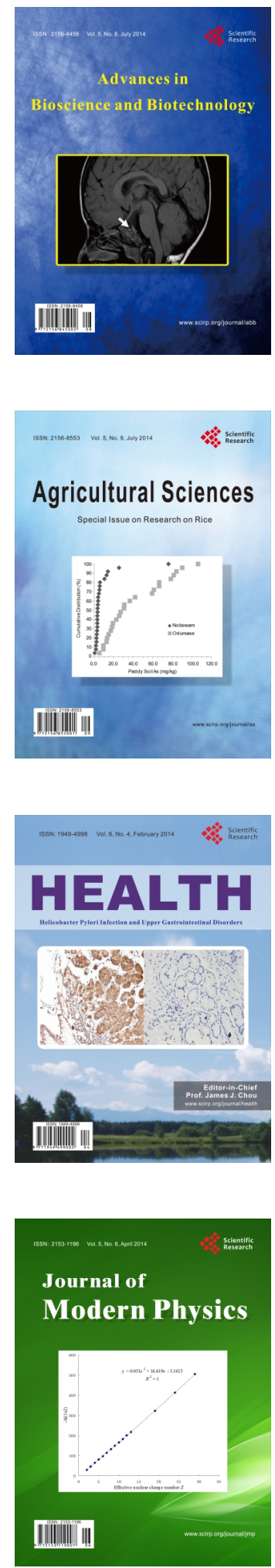
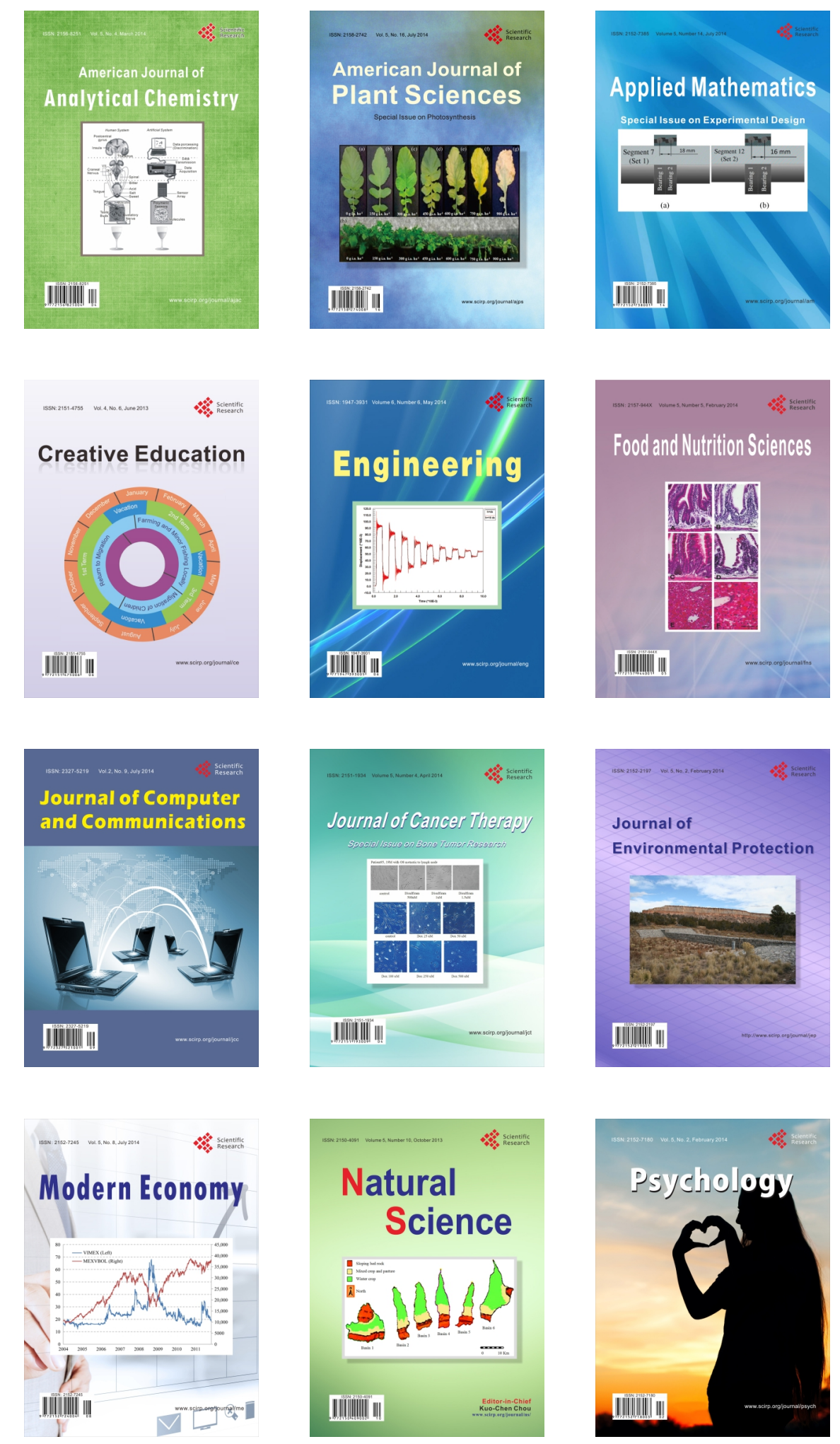